\title{
Aktivitas Ekstrak Daun Jarak Kepyar (Ricinus communis Linnaeus) terhadap Perkembangan Nematoda Meloidogyne spp. pada Tanaman Tomat (Lycopersicum esculentum Miller)
}

\author{
Activity of Castor Bean Leaves Extract (Ricinus Communis Linnaeus) to Development of \\ Nematode Meloidogyne Spp. on Tomato Plant (Lycopersicum esculentum Miller)

\section{Elisa Oktavia ${ }^{1)}$, Winarto ${ }^{1)^{*}}$, Eri Sulyanti ${ }^{1)}$} \\ 1) Program Studi Proteksi Tanaman, Fakultas Pertanian, Universitas Andalas, Padang \\ E-mail: winartosmd61@gmail.com \\ Diterima: 15 April 2021 Disetujui: 28 Juni 2021 Dipublikasi: 30 Juni 2021
}

\begin{abstract}
Meloidogyne spp. is one of the nematodes that cause root-knot on tomato plants. The botanical nematicide that potentially suppresses the nematode is castor bean leaves (Ricinus communis Linnaeus) extract. This research aimed to get the lethal concentration (LC50 and LC95) of castor bean leaves extract against nematode larvae in-vitro and their effect on the development of root-knot nematode (Meloidogyne spp.) in-planta on tomato plant. The research was carried out in Plant Pest and Disease Laboratory and Greenhouse of Agriculture Faculty, Universitas Andalas, using a completely randomized design (CRD) with two stages; in-vitro and in-planta. The research was used the experiment method in-vitro testing consists of six treatments and five replications, and in-planta testing consists of three treatments and nine replications. The result showed that the application of castor bean leaves extracts invitro can suppress Meloidogyne spp. larvae with LC50 by $0,27 \%$ and LC95 by $0,87 \%$. The application of castor bean leaves extract in-planta with treatment concentration $2 \times \mathrm{LC} 95$ $(1,74 \%)$ showed effectiveness by $74,69 \%$ against the developments of Meloidogyne spp. on tomato plant roots.
\end{abstract}

Keywords: Meloidogyne spp., Ricinus communis Linnaeus, root-knot nematode, tomato.

\section{PENDAHULUAN}

Tomat (Lycopersicum esculentum Miller) merupakan komoditas hortikultura yang penting dan banyak dibudidayakan petani. Menurut Hanindita (2008), tomat menjadi salah satu komoditas hortikultura yang bernilai ekonomi tinggi dan masih memerlukan penanganan serius, terutama dalam hal peningkatan hasil dan kualitas buahnya. Produktivitas tomat di Indonesia dari tahun 2016 hingga tahun 2018 mengalami peningkatan yaitu 15,31 ton/ha, 17,31 ton/ha dan 18,14 ton/ha.
Sumatera Barat mempunyai potensi sebagai produsen tomat karena iklim dan lingkungan yang memenuhi syarat bagi pertumbuhan dan perkembangannya. Terjadi peningkatan produktivitas tomat pada tahun 2016 hingga tahun 2018 yaitu 27,78 ton/ha, 30,21 ton/ha dan 36,61 ton/ha (Badan Pusat Statistik dan Direktorat Jenderal Hortikultura, 2019). Akan tetapi, produktivitas tomat tersebut masih tergolong sangat rendah jika dibandingkan dengan produktivitas optimal tomat yang dapat mencapai 50 ton/ha (Syukur et al., 2015). 
Salah satu penyebab rendahnya produktivitas tomat adalah serangan nematoda Meloidogyne spp. (Shiddiqui et al., 2014) yang menyebabkan penyakit bengkak akar (Amin, 2010). Infeksi nematoda menyebabkan penurunan fungsi sistem perakaran dan gangguan pada jaringan berkas pengangkut sehingga tanaman menjadi layu terutama dalam keadaan lingkungan yang kering, pertumbuhan terhambat, tanaman kerdil, dan klorosis (Panggeso, 2010). Tanaman juga menjadi rentan dan mudah terserang OPT lain seperti kelompok bakteri, jamur maupun virus. Serangan Meloidogyne spp. menyebabkan kerusakan sebesar 68,3\% (Khotimah et al., 2020), dan menurunkan produksi tomat dunia mencapai $20 \%$ per tahun (Prasasti, 2012).

Meloidogyne spp. merupakan OPT yang bersifat parasit obligat dan menyerang berbagai jenis tanaman dari beberapa famili (polifag). Sebanyak 60 spesies nematoda dari genus Meloidogyne spp. menyebabkan bengkak akar pada tanaman, empat diantaranya adalah $M$. incognita, $M$. javanica, $M$. arenaria, dan M. hapla (Gharabadiyan et al., 2012). Meloidogyne spp. memiliki tingkat kelimpahan yang paling tinggi dibandingkan nematoda parasit lain (Pradana, 2014).

Berbagai teknik pengendalian telah dilakukan, antaranya penggunaan varietas tahan (toleran), teknik budidaya (bahan organik, pemupukan, penutup tanah, pergiliran tanaman), pestisida nabati (biji mimba, jarak), agen hayati (jamur Arthrobotrys, bakteri Pasteuria penetrans), dan pestisida sintetik (Mustika, 2005). Usaha pengendalian nematoda secara sintetis dilakukan pula dengan menggunakan karbofuran pada konsentrasi 3 gram/tanaman, yang menunjukkan efektivitas penekanan 73,4\% (Harni dan Samsudin, 2015). Namun, penggunaan secara kontinyu dapat menimbulkan dampak negatif seperti kerusakan pada tanah, resistensi, resurgensi, dan resiko keracunan pada manusia serta bahaya lainnya yang berkaitan dengan lingkungan. Untuk itu perlu dipikirkan alternatif lain yang lebih ramah lingkungan seperti pemanfaatan nematisida nabati.

Menurut Colenta (2019), pemanfaatan bakteri antagonis Bacillus pseudomycoides dapat menekan perkembangan Meloidogyne spp. pada tanaman tomat. Dewi (2020) melaporkan bahwa pemberian jamur Paecilomyces lilacinus dengan dosis $20 \mathrm{~g} / 5 \mathrm{~kg}$ tanah, mampu mengendalikan Meloidogyne spp. pada tanaman tomat. Pemanfaatan nematisida nabati dapat juga dapat dilakukan. Liu et al. (2014) melaporkan, terdapat empat ekstrak yang menyebabkan $100 \%$ mortalitas Meloidogyne incognita pada $1 \mathrm{mg} / \mathrm{ml}$ selama 72 jam diantaranya adalah daun jarak kepyar (Ricinus communis Linnaeus).

Menurut Safrina et al. (2017), daun jarak kepyar mengandung senyawa metabolit sekunder yaitu alkaloid, flavono-id, fenolik dan terpenoid yang bersifat toksik terhadap mikroorganisme. Adegbite dan Adeiyan (2005) menambahkan, jarak kepyar sangat beracun bagi nematoda bengkak akar karena bersifat ovicidal yang dapat mempengaruhi perkembangan embrionik atau telurnya. Sifat ini meningkat seiring dengan meningkatnya periode paparan. Penelitian ini bertujuan untuk mendapatkan konsentrasi ekstrak daun jarak kepyar yang dapat mematikan (LC50 dan LC95) larva nematoda secara in-vitro dan pengaruhnya terhadap perkembangan nematoda bengkak akar (Meloidogyne spp.) secara in-planta pada tanaman tomat.

\section{METODOLOGI}

Penelitian dilaksanakan di Laboratorium Bioekologi Serangga, Laboratorium Pengendalian Hayati dan Rumah Kaca Fakultas Pertanian Universitas Andalas pada bulan Juni hingga September 2020. 


\section{Metode}

Penelitian dilaksanakan dalam dua tahap yaitu secara in-vitro dan in-planta. Penelitian secara in-vitro menggunakan Rancangan Acak Lengkap (RAL) dengan 6 perlakuan dan 5 ulangan dan pengujian in-planta dengan 3 perlakuan dan 9 ulangan. Tanaman jarak kepyar yang digunakan berasal dari Dadok Tunggul Hitam, Kecamatan Koto Tangah, Padang. Sumber inokulum kelompok telur Meloidogyne spp. berasal dari Nagari Alahan Panjang, Kecamatan Lembah Gumanti, Kabupaten Solok Provinsi Sumatera Barat. Konsentasi perlakuan secara invitro didapat dari hasil uji pendahuluan dengan konsentrasi $0,25 \%$ dan $0,5 \%$ yaitu $0,0,10 \%, 0,16 \%, 0,25 \%, 0,39 \%$, dan $0,61 \%$.

Pengujian secara in-planta dilaksanakan setelah diperoleh nilai $\mathrm{LC}_{95}$ hasil pengujian in-vitro melalui analisis probit. Perlakuan yang disiapkan adalah kontrol (tanpa perlakuan), ekstrak daun tanaman jarak kepyar 2xLC95 (Konsentrasi 1,74 \%) dan furadan berbahan aktif karbofuran 3\% (dosis 3 gram/ polybag).

\section{Pelaksanaan}

Pembuatan ekstrak daun jarak kepyar

Daun jarak kepyar dibersihkan dan dipotong kecil, setelah itu dikeringanginkan selama 7 hari. Daun yang sudah kering dihaluskan menggunakan blender dan diayak untuk mendapatkan serbuk yang halus. Serbuk daun ditimbang sebanyak 100 gram dan dimasukkan ke dalam labu erlenmeyer 1 liter, kemudian ditambahkan dengan 1 liter larutan metanol dan dimaserasi selama $3 \times 24$ jam pada suhu ruang. Hasil maserasi disaring menggunakan corong kaca (diameter $9 \mathrm{~cm}$ ) yang dilapisi kertas saring dan ditampung di labu erlenmeyer 1 liter. Corong kaca (diameter $5 \mathrm{~cm}$ ) digunakan untuk menyaring hasil saringan pertama yang dilapisi dengan kertas saring Whatmann no.41 dan ditampung dalam labu uap.
Rotary evaporator digunakan pada suhu $60^{\circ} \mathrm{C}$ dan tekanan 240 mbar untuk memisahkan ekstrak daun dan pelarutnya. Metanol yang diperoleh dari hasil penguapan dapat digunakan kembali untuk maserasi ampas atau serbuk daun sebanyak 3 kali pengulangan. Ekstrak yang telah pekat dipindahkan ke dalam botol kaca. Penentuan konsentrasi pada uji lanjut ekstrak daun jarak kepyar didasarkan pada uji pendahuluan (Ferdiyansyah, 2019).

\section{Persiapan dan perbanyakan sumber inokulum nematoda}

Sumber inokulum berasal dari kelompok telur nematoda Meloidogyne spp. yang diperoleh dari perakaran tanaman tomat yang sudah terinfeksi di Nagari Alahan Panjang, Kecamatan Lembah Gumanti, Kabupaten Solok, Provinsi Sumatera Barat. Akar tanaman tomat yang bergejala bengkak dibawa ke Laboratorium Bioekologi Serangga dan dicuci. Kelompok telur diambil dan dikumpulkan ke dalam cawan petri. Perbanyakan dilakukan dengan menginokulasikan 5 kelompok telur pada tanaman tomat berumur 21 hari. Saat tanaman berumur 45 hari setelah inokulasi maka dilakukan ekstraksi telur nematoda dengan cara mengambil beberapa kelompok telur pada perakaran tomat dan dikumpulkan dalam cawan petri. Larutan suspensi dibuat dengan cara memasukkan kelompok telur nematoda dalam larutan $\mathrm{NaOCL}$ 0,5\%. Untuk setiap polybag dibutuhkan \pm 1000 telur nematoda yang diinokulasikan pada perakaran tanaman tomat sebagai sumber inokulum nematoda (Ferdiyansyah, 2019).

\section{Pengujian Secara In-vitro Uji pendahuluan}

Uji pendahuluan dilakukan untuk mengetahui mortalitas larva nematoda. Ekstrak daun jarak kepyar yang telah dipekatkan dengan rotary evaporator ditimbang menggunakan timbangan anali- 
tik sebesar 0,0625 gram untuk konsentrasi $0,25 \%$ dan 0,125 gram. Untuk konsentrasi $0,5 \%$ dimasukkan ke dalam labu volumetri berukuran $25 \mathrm{ml}$. Kemudian ekstrak dilarutkan dengan pelarut organik campuran aseton : metanol (3:1) sebanyak $1 \%$ dan larutan tween $80 \%$ sebanyak $0.2 \%$ dari volume larutan ekstrak. Aquades ditambahkan hingga garis tera setelah larutan homogen. Sebanyak 15 larva dimasukkan ke dalam cawan petri dengan 3 kali pengulangan. Aplikasi ekstrak daun jarak kepyar dilakukan dengan cara diteteskan menggunakan pipet tetes ke dalam cawan petri yang telah berisi larva Meloidogyne spp. Ialu diamati mortalitas larva. Pada uji lanjut, kisaran konsentrasi perlakuan diperoleh dengan menggunakan rumus $X^{4}$ (Lina, 2014).

\section{Uji lanjut}

Pengujian lebih lanjut dilakukan untuk mendapatkan nilai LC50 dan LC95 dari ekstrak daun jarak kepyar. Ekstrak dibagi menjadi beberapa konsentrasi perlakuan dan diaplikasikan ke dalam cawan petri yang telah berisi 15 larva, dan disiapkan untuk 5 kali ulangan, sehingga setiap perlakuan terdiri dari 75 sampel larva nematoda dan dilakukan pengamatan 24 jam setelah aplikasi (Ferdiyansyah, 2019).

\section{Analisis Probit}

Analisis probit dilakukan untuk menentukan nilai Median Lethal Concentration (LC50) dan Letal Concentration (LC95) dari masing-masing perlakuan. Nilai LC50 dan LC95 dihitung dengan menggunakan program computer Analisis Probit POLO PC. Perhitungan dilakukan dengan menggunakan metode Finney (1971).

\section{Parameter Pengamatan \\ Efektivitas penekanan terhadap perkem- bangan Meloidogyne spp.}

Untuk melihat efektivitas penekanan ekstrak daun jarak kepyar terhadap jumlah bengkak akar, jumlah kelompok telur, jumlah telur dalam kelompok telur dan jumlah nematoda dalam sampel tanah, digunakan rumus (Oclarit dan Cumagun, 2009):

$K P=\frac{K-P}{K} X 100 \%$ Rumus 1

Keterangan:

$\mathrm{KP}=$ Kemampuan penekanan

$P=$ Perlakuan

$\mathrm{K}=$ Kontrol

Efektivitas terhadap pertumbuhan tanaman

Efektivitas ekstrak daun jarak kep-yar terhadap pertumbuhan tanaman dihi-tung dengan menggunakan rumus:

$E P=\frac{P-K}{K} X 100 \%$ Rumus 2

Keterangan:

$E P=$ Efektifitas perlakuan

$\mathrm{P}=$ Perlakuan

$\mathrm{K}=$ Kontrol

\section{Pengujian Secara In-planta \\ Penyiapan media tanam}

Media tanam yang digunakan adalah campuran tanah, pasir dan pupuk kandang dengan perbandingan volume 2:1:1. Media tanam disterilisasi menggunakan metode tyndalisasi dengan cara dikemas dalam plastik kaca ukuran $5 \mathrm{~kg}$ dan dimasukkan ke dalam wadah steril berupa dandang dengan suhu $150^{\circ} \mathrm{C}$ selama 60 menit. Media tanam didiamkan selama 24 jam dan sterilisasi diulangi sebanyak 3 kali, media tanam yang sudah steril dimasukkan ke dalam polybag ukuran $5 \mathrm{~kg}$ dan dibiarkan di rumah kaca selama 7 hari.

\section{Penyemaian benih}

Benih tanaman tomat yang digunakan adalah varietas Warani. Benih disemai pada tray yang telah berisi media tanam steril. Setelah penyemaian kemudian dilakukan pemeliharaan selama 21 hari, setelah itu dipindahkan ke polybag ukuran $5 \mathrm{~kg}$. Bibit yang dipindahkan adalah bibit dengan tinggi seragam dan memiliki pertumbuhan yang baik. 
Persiapan telur Meloidogyne spp.

Telur nematoda diperoleh dari akar tanaman tomat yang didapat dari perbanyakan sumber inokulum nematoda saat tanaman berumur 45 hari setelah inokulasi, kemudian digunakan sebagai perbanyakan. Akar tanaman dibawa ke Laboratorium Bioekologi Serangga, kemudian dicuci dan diamati kelompok telurnya. Suspensi dibuat dengan cara mengumpulkan beberapa kelompok telur nematoda dan dilarutkan dalam $\mathrm{NaOCl} 0.5 \%$, suspensi diinokulasikan pada perakaran tanaman tomat yang digunakan sebagai sumber inokulum nematoda.

\section{Inokulasi telur Meloidogyne spp. ke dalam media tanah}

Inokulasi nematoda Meloidogyne spp. dilakukan dengan cara menuangkan suspensi berisi \pm 1000 telur nematoda Meloidogyne spp. per polybag sekitar lubang tanam tanaman tomat. Inokulasi dilakukan 2 hari sebelum penanaman tanaman tomat.

\section{Aplikasi ekstrak daun tanaman jarak kepyar}

Aplikasi esktrak daun jarak kepyar pada konsentrasi $2 \times$ LC95 (nilai 1,74\%) dilakukan $4 x$ aplikasi yaitu pada saat inokulasi, 2, 4, 6 hari setelah inokulasi telur nematoda ke dalam media tanam. Aplikasi ekstrak dilakukan dengan menyemprotkan larutan ekstrak sebanyak $100 \mathrm{ml}$ setiap polybag untuk setiap perlakuan konsentrasi larutan.

\section{Penanaman dan pemeliharaan}

Penanaman dilakukan saat bibit berumur 21 hari setelah benih tomat disemai yang dilakukan dengan cara memindahkan bibit tanaman ke polybag yang berisi media tanam steril. Bibit yang dipindahkan adalah bibit dengan tinggi seragam dan memiliki pertumbuhan yang baik. Pemeliharaan tanaman tomat dilakukan setiap hari dengan melakukan penyiraman pada pagi dan sore hari.
Pengendalian hama dan gulma dilakukan langsung secara fisik mekanis saat ditemukan pada tanaman dalam polybag.

\section{Parameter Pengamatan}

Pengamatan dilakukan ketika tanaman berumur 45 hari setelah tanam, dengan mencabut akar tanaman dan dicuci. Parameter pengamatan adalah:

\section{Jumlah bengkak akar/tanaman}

Pengamatan bengkak akar dilakukan dengan menghitung dan mencatat jumlah bengkak akar tanaman tomat yang telah dicuci menggunakan kaca pembesar dan hand tally counter. Efektivitas masingmasing perlakuan dihitung menggunakan Rumus 1.

\section{Jumlah kelompok telur/tanaman}

Perhitungan kelompok telur nematoda diamati dengan bantuan kaca pembesar dan hand tally counter. Kemudian dilakukan pengamatan dibawah mikroskop dengan ciri berbentuk bulat atau lonjong berwarna kekuning-kuningan, kelompok telur nematoda dihitung dan dicatat. Efektivitas masing-masing perlakuan dihitung menggunakan Rumus 1.

\section{Jumlah telur tiap kelompok telur}

Perhitungan jumlah telur tiap kelompok telur dilakukan dengan mengambil sampel kelompok telur sebanyak \pm 5 kelompok telur tiap polybag/ perakaran tanaman uji. Masukkan kelompok telur ke dalam cawan petri yang diberi garis bantu, tiap sampel ditetesi sebanyak 2-3 tetes $\mathrm{NaOCl} 5 \%$. Kemudian diamati di bawah mikroskop stereobinokuler dan dihitung menggunakan hand tally counter. Menurut Winarto (2015), dalam satu kelompok telur dapat berisi antara 400-1000 telur bahkan lebih jika tanaman inang dan lingkungannya cocok. Efektivitas masing-masing perlakuan dihitung menggunakan Rumus 1.

\section{Jumlah nematoda dalam sampel tanah}

Perhitungan jumlah nematoda pada akar tanaman tomat dilakukan dengan 
ekstraksi tanah menggunakan corong Baermann yang telah dimodifikasi oleh Ir. Winarto, MS. Sampel tanah pada setiap polybag diambil dan diekstraksi sebanyak 300 gram. Nematoda yang terdapat di dalam tanah perakaran tomat dihitung dengan hand tally counter dibawah mikroskop stereobinokuler.

\section{Tinggi tanaman $(\mathrm{cm})$}

Pengukuran tinggi tanaman dilakukan satu kali dalam seminggu setelah tanaman dipindahkan ke polybag sampai umur tanaman 45 hari. Tinggi tanaman diukur dari pangkal batang sampai titik tumbuh batang utama menggunakan alat bantu meteran. Efektivitas masing-masing perlakuan dihitung menggunakan Rumus 2 .

\section{Jumlah daun}

Pengamatan jumlah daun tanaman tomat diamati dengan menghitung jumlah daun yang muncul pada tanaman dimulai pada hari ke-7 setalah aplikasi perlakuan. Efektivitas masing-masing perlakuan dihitung menggunakan Rumus 2.

\section{Umur berbunga (hari)}

Pengamatan muncul bunga pertama dilakukan setiap hari sampai bunga pertama muncul dan mekar sempurna. Efektivitas masing-masing perlakuan dihitung menggunakan Rumus 2.

\section{Biomassa tanaman (g)}

Berat basah dan berat kering tanaman ditimbang pada umur 45 hari setelah tanam (HST). Tanaman dicabut dengan akarnya secara hati-hati, dibersihkan lalu ditimbang (berat basah). Penimbangan berat kering tanaman dilakukan setelah tanaman dikeringkan dalam oven pada suhu $70^{\circ} \mathrm{C}$ selama 48 jam.

\section{HASIL}

\section{Pengujian In-vitro \\ Mortalitas larva Meloidogyne spp.}

Ekstrak daun jarak kepyar mampu mematikan larva Meloidogyne spp. pada uji pendahuluan. Peningkatan konsentrasi, telah meningkatkan mortalitas larva. Mortalitas tertinggi terjadi pada konsentrasi $0,50 \%$, yaitu sebesar $80,00 \%$ (Tabel 1). Setelah dilakukan uji lanjut, aplikasi ekstrak daun jarak kepyar bisa mematikan sekitar 92\% larva pada konsentrasi 0,61\% dan berbeda nyata dengan perlakuan lainnya. Sementara itu, diperoleh nilai LC 50 pada konsentrasi $0,27 \%$ dan LC95 terjadi pada konsentrasi 0,87\% (Tabel 2).

Tabel 1. Mortalitas larva Meloidogyne spp. 24 jam setelah aplikasi ekstrak daun jarak kepyar pada uji pendahuluan

\begin{tabular}{cc}
\hline Konsentrasi (\%) & Mortalitas (\%) \\
\hline 0,50 & 80,00 \\
0,25 & 53,33 \\
0 & 0,00 \\
\hline
\end{tabular}

Tabel 2. Mortalitas larva Meloidogyne spp. 24 jam setelah aplikasi beberapa konsentrasi ekstrak daun jarak kepyar

\begin{tabular}{cccc}
\hline Konsentrasi (\%) & Mortalitas (\%) \pm SD & LC50 & LC95 \\
\hline 0,61 & $92,00 \pm 13,80 \mathrm{a}$ & & \\
0,39 & $65,33 \pm 9,80 \mathrm{~b}$ & & \\
0,25 & $44,00 \pm 6,60 \mathrm{c}$ & & \\
0,16 & $24,00 \pm 3,60 \mathrm{~d}$ & 0,27 & 0,87 \\
0,10 & $12,00 \pm 1,80 \mathrm{e}$ & & \\
0 & $1,33 \pm 0,20 \mathrm{e}$ & & \\
\hline
\end{tabular}

Rata-rata nilai pada kolom yang sama yang diikuti huruf kecil yang sama berbeda tidak nyata berdasarkan uji LSD pada taraf $5 \%$. 


\section{Pengujian In-planta}

\section{Jumlah bengkak akar/tanaman}

Ekstrak daun jarak kepyar dapat menurunkan jumlah bengkar akar secara signifikan, dan tidak berbeda nyata dengan nematisida sintetik, bahkan efektifitas penekanan melebih kemampuan nematisida sintetik (Tabel 3). Tampilan akar tanaman tomat setiap perlakuan disajikan pada Gambar 4.

Tabel 3. Rata-rata jumlah bengkak akar setelah perlakuan, 45 hari setelah tanam (HST)

\begin{tabular}{lcc}
\hline \multicolumn{1}{c}{ Perlakuan } & $\begin{array}{c}\text { Jumlah Bengkak Akar/ tanaman } \\
\pm \text { SD }\end{array}$ & Efektivitas (\%) \\
\hline Kontrol & $679,11 \pm 3,30 \mathrm{a}$ & 0,00 \\
Ekstrak daun jarak kepyar & $122,00 \pm 8,35 \mathrm{~b}$ & 82,04 \\
Nematisida sintetik & $223,22 \pm 9,25 \mathrm{~b}$ & 67,13 \\
\hline
\end{tabular}

Rata-rata nilai pada kolom yang sama yang diikuti huruf kecil yang sama berbeda tidak nyata berdasarkan uji LSD pada taraf $5 \%$.
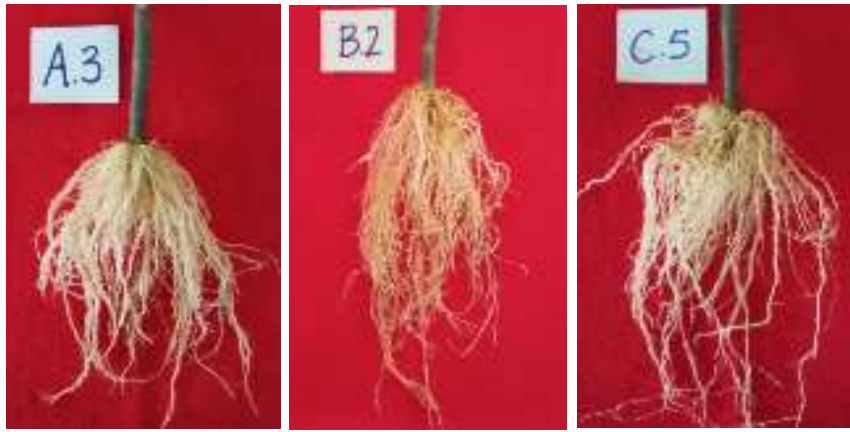

Gambar 4. Perbandingan akar tanaman tomat setelah aplikasi: A) ekstrak daun jarak kepyar, B) nematisida sintetik berbahan karbofuron, C) Kontrol

Jumlah kelompok telur dan jumlah telur per kelompok telur

Ekstrak daun jarak kepyar mampu menekan jumlah kelompok telur Meloidogyne spp. dan jumlah telur pada setiap kelompok telur. Kemampuan tersebut tidak berbeda nyata dengan nematisida sintetik. Efektivitas penekanan terhadap kelompok telur adalah $86,72 \%$ dan penekanan terhadap jumlah telur per kelompok 60,28\% (Tabel 4).

Tabel 4. Jumlah kelompok telur dan jumlah telur tiap kelompok telur pada permukaan perakaran tanaman tomat setelah perlakuan, 45 hari setelah tanam (HST)

\begin{tabular}{lrrrr}
\hline \multicolumn{1}{c}{ Perlakuan } & $\begin{array}{c}\text { Jumlah kelompok } \\
\text { telur/ tanaman } \pm \text { SD }\end{array}$ & $\begin{array}{c}\text { Efektivitas } \\
(\%)\end{array}$ & $\begin{array}{c}\text { Jumlah telur tiap } \\
\text { kelompok telur } \pm \text { SD }\end{array}$ & $\begin{array}{c}\text { Efektivitas } \\
(\%)\end{array}$ \\
\hline Kontrol & $20,11 \pm 1,44 \mathrm{a}$ & 0,00 & $390,64 \pm 1,95 \mathrm{a}$ & 0,00 \\
Ekstrak daun jarak kepyar & $2,67 \pm 1,21 \mathrm{~b}$ & 86,72 & $155,17 \pm 8,83 \mathrm{~b}$ & 60,28 \\
Nematisida sintetik & $5,00 \pm 1,57 \mathrm{~b}$ & 75,14 & $219,06 \pm 9,24 \mathrm{~b}$ & 43,92 \\
\hline
\end{tabular}

Rata-rata nilai pada kolom yang sama yang diikuti huruf kecil yang sama berbeda tidak nyata berdasarkan uji LSD pada taraf $5 \%$

\section{Jumlah nematoda dalam sampel tanah}

Ekstrak daun jarak kepyar pada perakaran tanaman tomat dapat menekan jumlah nematoda dalam sampel tanah. Efektivitas penekanan setara dengan kemampuan nematisida sintetik (Tabel 5). 
Tabel 5. Jumlah larva nematoda Meloidogyne spp dalam sampel tanah perakaran tanaman tomat setelah perlakuan, 45 hari setelah tanaman (HST).

\begin{tabular}{lcc}
\hline \multicolumn{1}{c}{ Perlakuan } & $\begin{array}{c}\text { Jumlah larva nematoda dalam } \\
300 \mathrm{~g} \text { Sampel Tanah } \pm \text { SD }\end{array}$ & Efektivitas (\%) \\
\hline Kontrol & $57,22 \pm 1,07 \mathrm{a}$ & 0,00 \\
Ekstrak daun jarak kepyar & $17,33 \pm 3,05 \mathrm{~b}$ & 69,71 \\
Nematisida sintetik & $17,33 \pm 2,26 \mathrm{~b}$ & 69,71 \\
\hline
\end{tabular}

Rata-rata nilai pada kolom yang sama yang diikuti huruf kecil yang sama berbeda tidak nyata berdasarkan uji LSD pada taraf $5 \%$

Tinggi dan jumlah daun tanaman tomat

Ekstrak daun jarak kepyar tidak mempengaruhi tinggi tanaman tomat, tapi mampu meningkatkan jumlah daun, meskipun memiliki efektivitas yang rendah (Tabel 6, Gambar 5).

Tabel 6. Tinggi dan jumlah daun tanaman tomat setelah perlakuan, 45 hari setelah tanam (HST).

\begin{tabular}{lcccc}
\hline \multicolumn{1}{c}{ Perlakuan } & $\begin{array}{c}\text { Tinggi Tanaman }(\mathrm{cm}) \\
\pm \text { SD }\end{array}$ & $\begin{array}{c}\text { Efektivitas } \\
(\%)\end{array}$ & $\begin{array}{c}\text { Jumlah daun/ } \\
\text { tanaman } \pm \text { SD }\end{array}$ & $\begin{array}{c}\text { Efektivitas } \\
(\%)\end{array}$ \\
\hline Kontrol & $133,22 \pm 14,07 \mathrm{a}$ & 0,00 & $18,89 \pm 1,05 \mathrm{~b}$ & 0,00 \\
Ekstrak daun jarak kepyar & $143,11 \pm 13,67 \mathrm{a}$ & 7,42 & $21,56 \pm 3,91 \mathrm{a}$ & 14,13 \\
Nematisida sintetik & $134,11 \pm 6,95 \mathrm{a}$ & 0,67 & $20,00 \pm 2,06 \mathrm{ab}$ & 5,88 \\
\hline
\end{tabular}

Rata-rata nilai pada kolom yang sama yang diikuti huruf kecil yang sama berbeda tidak nyata berdasarkan uji LSD pada taraf $5 \%$.

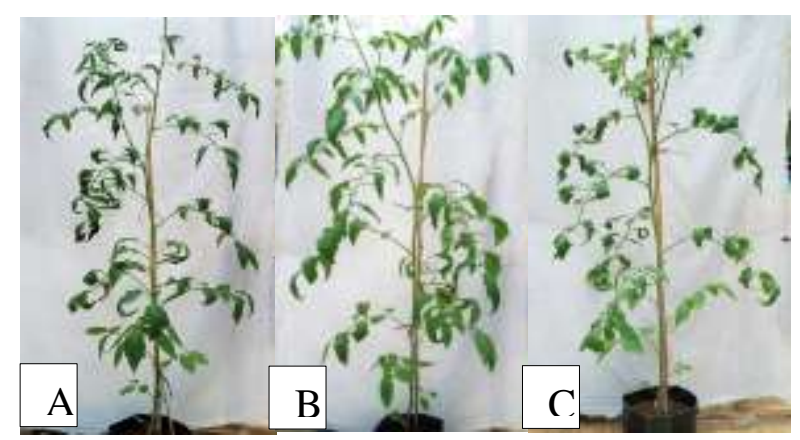

Gambar 5. Tanaman tomat 45 hari setelah tanam (HST) (A)Tanaman tomat perlakuan ekstrak daun jarak kepyar, (B)Tanaman tomat perlakuan nematisida sintetik, (C) Tanaman tomat perlakuan kontrol

\section{Umur berbunga (hari)}

Ekstrak daun jarak kepyar yang diaplikasikan pada akar tanaman tomat tidak mempengaruhi umur berbunga tanaman tomat, dengan efektivitas tergolong rendah (Tabel 7).

Tabel 7. Umur berbunga tanaman tomat setelah perlakuan, 45 hari setelah tanam (HST).

\begin{tabular}{lcc}
\hline \multicolumn{1}{c}{ Perlakuan } & Umur Berbunga (HST) \pm SD & Efektivitas (\%) \\
\hline Kontrol & $38,78 \pm 2,86$ a & 0,00 \\
Ekstrak daun jarak kepyar & $36,78 \pm 2,76$ a & 5,16 \\
Nematisida sintetik & $36,22 \pm 2,22 \mathrm{a}$ & 6,60 \\
\hline
\end{tabular}

Rata-rata nilai pada kolom yang sama yang diikuti huruf kecil yang sama berbeda tidak nyata berdasarkan uji LSD pada taraf $5 \%$. 


\section{Biomassa tanaman}

Ekstrak daun jarak kepyar yang diaplikasikan pada akar tanaman tomat juga tidak mempengaruhi berat kering dan berat basah tanaman, begitu juga dengan dengan nematisida sintetik (Tabel 8).

Tabel 8. Berat basah dan berat kering tanaman tomat setelah perlakuan, 45 hari setelah tanam (HST)

\begin{tabular}{lcccc}
\hline \multicolumn{1}{c}{ Perlakuan } & $\begin{array}{c}\text { Berat basah } \\
\text { (gram) } \pm \text { SD }\end{array}$ & $\begin{array}{c}\text { Efektivitas } \\
\text { (\%) }\end{array}$ & $\begin{array}{c}\text { Berat kering } \\
\text { (gram) } \pm \text { SD }\end{array}$ & $\begin{array}{c}\text { Efektivitas } \\
\text { (\%) }\end{array}$ \\
\hline Kontrol & $200,78 \pm 17,38$ a & 0,00 & $44,51 \pm 11,73$ a & 0,00 \\
Ekstrak daun jarak kepyar & $202,00 \pm 23,24$ a & 0,61 & $41,25 \pm 16,86$ a & $-7,32$ \\
Nematisida sintetik & $210,14 \pm 41,42$ a & 4,66 & $53,83 \pm 14,85$ a & 20,94 \\
\hline
\end{tabular}

Rata-rata nilai pada kolom yang sama yang diikuti huruf kecil yang sama berbeda tidak nyata berdasarkan uji LSD pada taraf $5 \%$.

\section{PEMBAHASAN}

Hasil pengujian secara in-vitro menemukan bahwa ekstrak daun jarak kepyar mampu mematikan larva Meloidogyne spp., mortalitas meningkat seiring dengan meningkatnya konsentrasi (Tabel 1 , Tabel 2). Hal ini karena semakin tinggi konsentrasi, semakin tinggi pula senyawa toksik yang terkandung dalam ekstrak daun jarak kepyar seperti senyawa risin. Prijono (2008) menyatakan, semakin pekat konsentrasi larutan maka semakin banyak kandungan bahan aktif yang dapat mengganggu proses metabolisme dari serangga uji.

Menurut Wahyono dan Rachmat (2000), semua bagian tumbuhan jarak kepyar beracun untuk nematoda, jamur, dan serangga karena kandungan bioaktif risin $80-90 \%$ dan sisanya minyak castor. Risin merupakan racun utama pada jarak kepyar bersifat toksik dan dapat menghambat sistesis protein (Audi et al., 2005). Rich et al. (1989) menambahkan, senyawa risin mengakibatkan penurunan mobilitas pada $M$. incognita (larva tahap 2) pada konsentrasi $20 \mu \mathrm{g} / \mathrm{ml}$. Safrina et al. (2017) menambahkan pula, hasil uji fitokimia daun jarak kepyar mengandung senyawa metabolit sekunder berupa alkaloid, flavonoid, fenolik dan terpenoid yang bersifat toksik terhadap mikroorganisme. Senyawa kimia tersebut menyebabkan penekanan terhadap perkembangan nematoda dan menyebabkan kematian pada larva Meloidogyne spp.

Beberapa senyawa metabolit sekunder seperti alkaloid dan flavonoid yang terdapat pada ekstrak daun jarak kepyar dapat menekan perkembangan Meloidogyne spp. yang dapat mengakibatkan kematian pada larva. Menurut Cania dan Setyaningrum (2013), flavonoid dan alkaloid dapat berperan sebagai racun perut sehingga mengakibatkan kematian larva. Prijono (2008) menyatakan, cara kerja senyawa metabolit sekunder yaitu mempengaruhi sistem otot yang menyebabkan kelumpuhan, kelainan perilaku dan kegagalan pada sistem pernafasan. Hal ini mengakibatkan ketidakseimbangan kandungan zat dalam cairan tubuh sehingga terjadi keracunan sel dan akhirnya menyebabkan kematian.

Ekstrak daun jarak kepyar dapat menurunkan jumlah bengkar akar, jumlah kelompok telur dan jumlah telur per kelompok secara signifikan, dan tidak berbeda nyata dengan nematisida sintetik, bahkan efektifitas penekanan melebih kemampuan nematisida sintetik (Tabel 3, Tabel 4). Ekstrak daun jarak kepyar juga dapat menekan jumlah nematoda dalam sampel tanah, dengan efektivitas penekanan setara dengan kemampuan nematisida sintetik (Tabel 5). Hal ini diduga karena adanya senyawa metabolit 
sekunder seperti alkaloid dan flavonoid yang terkandung dalam ekstrak daun Jarak Kepyar. Pendapat ini didukung oleh Adegbite dan Adeiyan (2005), jarak kepyar sangat beracun bagi nematoda bengkak akar yang disebabkan oleh sifat kimia dari ekstrak yang memiliki sifat ovicidal yang dapat mempengaruhi perkembangan telurnya. Senyawa alkaloid dan flavonoid menjadi kombinasi yang baik dalam menghambat penetasan telur Meloidogyne spp. melalui pengaruh berupa terganggunya perkembangan embrio sehingga telur tidak menetas. Menurut Huzni et al. (2015), senyawa tanin dapat melarutkan protein pada kulit telur nematoda pada tahap awal pembentukan larva, sehingga menyebabkan telur nematoda tidak menetas. Nezriyetti dan Novita (2012) menambahkan, efek tanin terhadap dinding sel kulit larva dapat memblokade respon otot nematoda terhadap asetilkolin sehingga nematoda menjadi lumpuh dan mati.

Ekstrak daun jarak kepyar sebagai nematisida nabati mempunyai nilai efektivitas lebih tinggi dibandingkan nematisida sintetik Furadan, dengan nilai efektivitas 74,69\%. Hal ini diduga karena kemampuan senyawa ricin pada ekstrak lebih tinggi dibandingkan dengan senyawa karbofuran 3\% yang terdapat pada nematisida sintetik dalam menekan perkembangan Meloidogyne spp. Liu et al. (2014) menyatakan bahwa jarak kepyar dapat menyebabkan mortalitas $M$. incognita mencapai $100 \%$ pada $1 \mathrm{mg} / \mathrm{ml}$ selama 72 jam. Bharadwaj dan Sharma (2006) menambahkan, kombinasi penggunaan jarak kepyar dan jamur mikoriza arbuskular mampu menekan perkembangan nematoda bengkak akar $M$. Incognita pada tanaman tomat dengan persentase $76,7 \%$.

Ekstrak daun jarak kepyar tidak mempengaruhi tinggi, umur berbunga, dan biomassa tanaman tomat tapi mempengaruhi jumlah daun, meskipun memiliki efektivitas yang rendah (Tabel 6 , Tabel 7, Tabel 8). Hal ini diduga pada umur 45 HST nematoda belum berkembang karena hanya satu siklus hidup dan belum banyak menyebabkan bengkak akar, sehingga tidak berpengaruh terhadap pertumbuhan tanaman. Namun pengaruh tersebut diduga akan terlihat saat nematoda sudah berkembang menjadi beberapa kali siklus hidup.

\section{KESIMPULAN}

Aplikasi ekstrak daun jarak kepyar (Ricinus communis Linnaeus) mampu menekan perkembangan nematoda bengkak akar (Meloidogyne spp.) dengan nilai LC50 sebesar $0,27 \%$ dan LC95 sebesar $0,87 \%$. Pemberian ekstrak daun jarak kepyar pada perakaran tanaman tomat dengan konsentrasi $1,74 \% \quad(2 x \quad$ LC95) menunjukkan efektivitas sebesar $74,69 \%$ dalam menekan perkembangan nematoda bengkak akar (Meloidogyne spp.).

\section{DAFTAR PUSTAKA}

Adegbite AA dan SO Adesiyan. 2005. Root extracts of plants to control root-knot nematode on edible soybean. World Journal of Agricultural Sciences 1(1): 18-21.

Amin N. 2010. Pengaruh perlakuan bubuk biji pepaya (Carica papaya Linnaeus) terhadap serangan nematoda Meloidogyne spp. pada tanaman tomat. Jurnal Fitomedika 7(1): 9-14.

Audi J, M Belson, M Patel, J Schier, dan J Osterloh. 2005. Ricin poisoning: a comprehensive review. Journal of American Medical Association 294(18): 2342-2351.

Badan Pusat Statistik dan Direktorat Jenderal Hortikultura. 2019. Kementerian Pertanian Republik Indonesia.go.id. [Diakses 8 Oktober 2019].

Bharadwaj A dan S Sharma. 2006. Biocontrol of Meloidogyne incognita in 
Lycopersicum esculentum with AM Fungi and Oil Cakes. Indian Institute of Technology. India.

Cania E dan E Setyaningrum 2013. Uji Efektivitas larvasida ekstrak daun legundi (Vitex Trifolia) terhadap larva Aedes aegypti. Universitas Lampung. Lampung.

Colenta FAUS. 2019. Potensi Bacillus sp. endofit indigenos terseleksi untuk pengendalian nematoda bengkak akar (Meloidogyne spp.) pada tanaman tomat (Lycopersicum esculentum Miller). [Skripsi]. Universitas Andalas. Padang.

Dewi MM. 2020. Uji dosis jamur Paecilomyces lilacinus (Thom) dalam substrat dedak padi untuk menghambat perkembangan nematoda bengkak akar (Meloidogyne spp.) pada tanaman tomat (Lycopersicum esculentum Miller). [Skripsi]. Universitas Andalas. Padang.

Ferdiyansyah A. 2019. Ekstrak daun tanaman jarak pagar (Jatropha curcas Linnaeus) untuk menekan perkembangan nematoda bengkak akar (Meloidogyne spp.) pada tanaman tomat (Lycopersicum esculentum Miller). [Skripsi]. Universitas Andalas. Padang.

Gharabadiyan F, S Jamali dan AA Yazdi. 2012. Weed hosts of root-knot nematodes in tomato fields. Journal of Plant Protection Research 52(2): 230-234.

Hanindita N. 2008. Penyakit karena bakteri, virus, nematoda dan kahat hara kompedium penyakit-penyakit kacang tanah. Graha Ilmu. Yogyakarta.

Harni R. dan Samsudin. 2015. Pengaruh formula bionematisida bakteri endofit Bacillus sp. terhadap infeksi nematoda Meloidogyne sp. pada tanaman kopi. Balai Penelitian Tanaman Industri dan Penyegar (3):143-150.
Huzni M, BT Rahardjo, dan H Tarno. 2015. Uji laboratorium ekstrak kirinyuh (Chromolaena odorata King \& Robinson) sebagai nematisida nabati terhadap Meloidogyne spp. (Chitwood). Jurnal HPT 3(1): 93-101.

Khotimah N, W Nyoman, dan S Made. 2020. Perkembangan populasi nematoda puru akar (Meloidogyne spp.) dan tingkat kerusakan pada beberapa tanaman familia Solanaceae. [Skripsi]. Universitas Udayana. Bali.

Lina EC. 2014. Pengembangan formulasi insektisida nabati berbahan ekstrak Brucea javanica, Piper aduncum, dan Tephrosia vogelii untuk pengendalian hama kubis Crocidolomia pavonana. [Disertasi]. Institut Pertanian Bogor. Bogor.

Liu XC, L Zhou, dan ZL Liu. 2014. Evaluation of nematicidal activity of ethanol extracts of Euphorbiaceae plants and constituents from Euphorbia fischeriana to Meloidogyne incognita (Kofoid and White) Chitwood. Journal of Entomology and Zoology 2(4): 311317.

Mustika I. 2005. Konsepsi dan strategi pengendalian nematoda parasit tanaman perkebunan di Indonesia. Balai Penelitian Tanaman Rempah dan Obat 4(1): 20-32.

Nezriyetti dan T Novita. 2012. Effectiveness of Jatropha curcas leaf extract to inhibits the development of Meloidogyne spp. nematode on tomato roots. Biospecies 5(2): 35-39.

Panggeso J. 2010. Analisa kerapatan populasi nematoda parasitik pada tanaman tomat (Lycopersicum esculentum Miller) asal Kabupaten Sigi Biromaru. Jurnal Agroland 7(3): 198204.

Pradana AP, D Putri, dan A Munif. 2014. Analisis populasi nematoda parasit pada lahan tanaman tomat dengan sistem tanam monokultur dan poli- 
kultur. Institut Pertanian Bogor. Bogor.

Prasasti WD. 2012. Makalah seminar umum strategi pengendalian nematoda puru akar (Meloidogyne spp.) pada tanaman tomat (Solanum lycopersicum). Universitas Gadjah Mada. Yogyakarta.

Prijono D dan Pudjianto. 2008. Pengembangan formulasi insektisida nabati yang dibakukan berbasis daun kacang babi (Tephrosia vogelii Hook F., Leguminosae) dan buah kemukus (Piper cubeba Lf., Piperaceae) (Laporan Research Grant Program B). Departemen Proteksi Tanaman IPB. Bogor.
Rich JR, GS Rahi, CH Opperman, and EL Davis. 1989. Influence of the castor bean (Ricinus communis) lectin (Ricin) on motility of Meloidogyne incognita. Nematropica 19(1): 99-103.

Safrina J, Nurhamidah dan D Handayani. 2017. Uji aktivitas antioksidan dan antibakteri ekstrak daun Ricinus Communis Linnaeus (Jarak Kepyar). Jurnal Pendidikan dan IImu Kimia 1 (1): 66-70.

Syukur M, HE Saputra dan H Rusli. 2015. Bertanaman tomat di musim hujan. Penebar Swadaya. Jakarta.

Wahyono D dan M Rachmat. 2000. Tanaman biofarmaka sebagai biopestisida. Departemen Pertanian RI. Jakarta. 